\title{
META-ANALYSIS: THE EFFECT OF OBESITY ON HYPERURICEMIA
}

\author{
Nita Putriasti Mayarestya \\ Masters Program in Public Health, Universitas Sebelas Maret
}

\begin{abstract}
Background: In the last few decades, the prevalence of hyperuricemia is increasing rapidly worldwide. Lifestyle factors like obesity, purine abundant diet and alcohol intake are determined to be independent predictors for the development of hyperuricemia. According to epidemiological studies on metabolic syndrome, hyperuricemia was found to be positively related to several indices, such as body mass index, waist circumference, and dyslipidemia. This study aimed to investigate the effect of obesity on hyperuricemia. Subjects and Method: A systematic review and meta analysis was conducted by collecting articles from PubMed, Science Direct, Google Scholar, and Springerlink databases. The determination of selected articles based on eligible criteria using PICO: (1) Population = adults aged $\geq 18$ years, (2) Intervention= obesity, (3) Comparison= non obese, and (4) Outcome= hyperuricemia. Keywords used ("Obesity" OR "Overweight") AND ("Hyperuricemia”) AND ("Cross Sectional”). The inclusion criteria were English full text, cross sectional study, reported adjusted odds ratio, and published from 2011 to 2021. The articles were collected by PRISMA flow diagram. The selected articles were quantitatively assessed using Review Manager 5.3.

Results: 8 studies from Brazil, China, Indonesia, Japan, Bangladesh were involved for meta-analysis. This study showed that obesity increased the risk of hyperuricemia 2.35 times than normal weight ( $\mathrm{aOR}=2.35 ; 95 \% \mathrm{CI}=1.59$ to $3.47 ; \mathrm{p}<0.001$ ).

Conclusion: Obesity increased the risk of hyperuricemia.
\end{abstract}

Keywords: obesity, hyperuricemia

\section{Correspondence:}

Nita Putriasti Mayarestya. Masters Program in Public Health, Universitas Sebelas Maret. Jl. Ir. Sutami 36A, Surakarta 57126, Central Java. Email: nmayarestya@gmail.com. Mobile: +6282323694969 . 